\title{
KRITIK KARL MARX TERHADAP KAPITALISME DAN SOSIALISME
}

\author{
Muthmainnah Sultan (90100118119) \\ Fakultas Ekonomi dan Bisnis Islam UIN Alauddin Makassar \\ E-mail : muthmainnahsultan7@gmail.com
}

Sistem ekonomi kapitalis adalah sistem perekonomian yang memberikan kebebasan secara penuh kepada setiap individu untuk melakukan kegiatan perekonomian seperti memproduksi barang, menjual barang, menyalurkan barang dan lain sebagainya. Kapitalisme biasanya melibatkan hak-hak individu dan sekelompok individu yang berperan sebagai orang-orang legal atau korporasikorporasi yang memperdagangkan barang-barang kapital, buruh, dan uang (Yan, 2016).

Ernest Mandel dalam buku Bagong Suyanto yang berjudul "Sosiologi Ekonomi:Kapitalisme dan Konsumsi di Era Masyarakat Post Modernisme" membahasa lebih perinci dan mengajukan lima ciri pokok dari ekonomi kapitalisme. Pertama, ditingkat produksi, corak kapitalis adalah produksi komoditas, untuk meraih keuntungan yang sebesar-besarnya. Kedua, produsksi dilandasi kepemilikan pribadi. Ketiga, produksi dioperasinalkan dalam rangka meraih mengusai pasar yang berada dibawah kendali persaingan. Keempat para kapitalis berupaya merauk keuntungan yang sebesar- besarnya dengan cara melakukan. Kelima, Tujuan terakhir dari porduksi adalah akumulasi capital (Sirajuddin \& Tamsir, 2019).

Kapitalisme menganggap kebebasan individu tanpa batas untuk mencari kekayaan peribadi adalah sebuah keharusan bagi individu. Ideologi ini membuka kran kebebasan kepada umat manusia seluas-luasnya tanpa ada batasan baik batasan keagamaan, sistem, tradisi, maupun nilai dan norma (Sirajuddin \& Tamsir, 2019). Manusia dapat mengeksploitasi semua sumber daya ekonomi yang dipandang akan memberikan kesejahteraan yang optimal baginya. Kapitalisme sangat menjunjung tinggi hak-hak kepemilikan individu terhadap sumber daya ekonomi. Dalam kapitalisme, individu berada di atas masyarakat. Sistem ekonomi 
kapitalis memberikan arah yang kuat terhadap sebuah sistem yang mengenal akan hak kepemilikan, bahkan hak kepemilikan merupakan salah satu ciri dalam sistem ekonomi kapitalis (Pangiuk, 1997). Demikian pula perekonomian kapitalis setiap warga dapat mengatur nasibnya sendiri sesuai. Namun Karl Marx mengkritik paham terkait dengan sistem kapitalisme.

Karl Marx mempunyai nama lengkap Karl Heinrich Marx. Ia dilahirkan pada tanggal 5 Mei 1818 M di kota Trier-Prusia sebelah perbatasan barat Jerman. Ia dilahirkan ditengah-tengah keluarga Yahudi. Karl Marx adalah tokoh fenomenal dalam bidang filsafat materialisme, Sosiologi dan ekonomi. Beberapa pemikirannya sangat revolusioner sehingga mampu merubah sejarah. Beberapa peristiwa dunia seperti revolusi rusia, revolusi china dan beberapa negara asia lainnya baik langsung maupun tidak langsung terinspirasi dari pemikiran Karl Marx (Kambali \& Gresik, n.d.).

Karl Marx mengkritik sistem ekonomi kapitalis, yang menurut pandangannya sistem tersebut telah membuat kaum buruh sengsara dan menderita. Marx menilai hubungan pemilik modal dan buruh selayaknya transaksi jual beli komoditi. Buruh menjual tenaganya kepada pemilik modal dan dipertukarkan dengah upah, sehingga pemilik modal mempunyai persepsi buruh (pemilik tenaga kerja) tidak ada bedanya dengan faktor produksi lainnya (komoditi) (Qomar, 2019). Sirkulasi pertukaran barang dan perubahan uang menjadi komoditas dan berubah lagi menjadi uang, di kenal dengan pola $\mathrm{M}-\mathrm{C}-\mathrm{M} .3$ Nilai lebih yang diambil oleh kaum kapitalis dari kaum buruh pada dasarnya adalah sebuah tindakan pencurian terhadap hak-hak kaum buruh yang di sebut Karl Marx sebagai tindakan eksploitasi. Modal atau kapital dapat diibaratkan seperti uang yang dipergunakan untuk memperoleh lebih banyak uang (Kambali \& Gresik, n.d.).

Marx menilai bahwa sistem ekonomi kapitalisme telah melakukan eksploitasi terhadap kaum buruh. Marx berargumen bahwa nilai suatu barang dihasilkan melalui proses produksi atas kerja buruh. Sedangkan kapitalisme mencuri nilai lebih tersebut (Shaikh, 2017). Lebih lanjut Marx memberikan pembelaan kepada faktor produksi tenaga kerja (buruh) untuk melakukan 
perlawanan. Lebih lanjut Marx ingin mewujudkan masyarakat tanpa kelas dan menjadi masyarkat sejahtera dengan sistem ekonomi sosialis (Qomar, 2019).

Ekonomi sosialis berasal dari pemikiran Karl marx dan Engel yang dimana sejarah Ekonomi sosialis ini berkaitan erat dengan sejarah materialism dunia Barat (Santoso, 2011). Lebih lanjut sistem ekonomi sosialis ini merupakan bentuk intensitas dari sistem kapitalisme sebelumnya. George stiger dalam buku Mark Skousen "Sejarah Pemikiran Ekonomi Sang Maestro" menyatakan terkait dengan kapitalisme merupakan gaya ekonomi yang memiliki kebebasan, persaingan bebas dan kepemilikan pribadi (Sirajuddin \& Tamsir, 2019). Sistem ekonomi kapitalisme kemudian dianggap menjadi penyebab tidak tercapainya kesejahteraan masyarakat yang adil, walaupun kapitalisme baik dalam kinerja ekonomi namun pemerataan kesejahteraan material belumlah sepenuhnya berhasil. Hal ini dapat dilihat dan dinilai dari terjadinya tingkat inflasi dan banyaknya pengangguran di negara negara maju yang menerapkan sistem ekonomi kapitalis yang kemudian menimbulkan kesenjangan sosial antara penduduk kaya dan miskin (Fuadi, 2016).

Sistem ekonomi sosialisme merupakan model ekonomi yang diatur oleh negara, dimana perdagangan dan aktivitas perekonomian sepenuhnya menjadi tanggungjawab negara (Effendi, 2019) akan tetapi bukan berarti ekonomi sosialis tidak memberikan kebebasan individu dalam aktivitas ekonomi, hak pribadi tetap diberikan kebebasan dalam melakukan aktivitas ekonomi namun tidak begitu leluasa dibandingkan dengan campur tangan pemerintah (Tho'in, 2015). 


\section{DAFTAR PUSTAKA}

Effendi, S. (2019). Perbandingan Sistem Ekonomi Islam Dengan Sistem Ekonomi Kapitalis dan Sosialis. JRAM (Jurnal Riset Akuntansi Multiparadigma), 6(2), $147-158$.

Fuadi, A. (2016). Negara Kesejahteraan (Welfare State) dalam Pandangan Islam dan Kapitalisme. JESI (Jurnal Ekonomi Syariah Indonesia), 5(1), 13-32.

Kambali, M., \& Gresik, S. A.-A. M. (n.d.). Pemikiran Karl Marx Tentang Struktur Masyarakat (Dialektika Infrastruktur Dan Suprastruktur).

Pangiuk, A. (1997). Kepemilikan Ekonomi Kapitalis Dan Sosialis (Konsep Tauhid Dalam Sistem Islam). Nalar Fiqh, 4(2), 220446.

Qomar, M. N. (2019). Kritik Karl Marx Terhadap Konsep Buruh Kapitalis Kajian Komparatif Ekonomi Syariah Atas Buku Das Kapital I. Proceedings of Annual Conference for Muslim Scholars, 3(1), 1003-1009.

Santoso, F. S. (2011). Reformasi Ekonomi Berbasis Bagi Hasil Belajar Dari Sistem Ekonomi Sosialis. Muqtasid: Jurnal Ekonomi Dan Perbankan Syariah, 2(2), 193-207.

Shaikh, S. A. (2017). A comparative study of views and the role of labor in Marxian, mainstream, and Islamic economics. In Labor in an Islamic Setting (pp. 131141). Routledge.

Sirajuddin, S., \& Tamsir, T. (2019). REKONSTRUKSI KONSEPTUAL KEPEMILIKAN HARTA PERSPEKTIF EKONOMI ISLAM (Studi Kritis Kepemilikan Harta Sistem Ekonomi Kapitalisme). Laa Maisyir: Jurnal Ekonomi Islam, 6(2), 211-225.

Tho'in, M. (2015). Konsep Ekonomi Islam Jalan Tengah (Kapitalis-Sosialis). Jurnal Ilmiah Ekonomi Islam, 1(03). 
Yan, R. H. (2016). Eksistensi Sistem Ekonomi Kapitalis di Indonesia. Jurnal Ilmiah Al-Syir'ah, 8(1). 